\title{
Alternative sources of data for alternative histories of standardisation
}

\author{
Stephan Elspaß ${ }^{1}$ (1)
}

Received: 8 May 2018 / Accepted: 30 May 2019 / Published online: 26 June 2019

(C) The Author(s) 2019

\begin{abstract}
What almost all accounts of standardisation histories have in common is a focus on printed, formal or literary texts from writing elites. While Haugen identified the written form of a language as "a significant and probably crucial requirement for a standard language" (Haugen in Am Anthropol 68:922-935, 1966a; Haugen, in: Bright (ed) Sociolinguistics, The Hague: Mouton, 1966b: 929; cf. also Haugen, in: Asher (ed) The encyclopedia of language and linguistics, Pergamon, Oxford, 1994: 4340), and while print certainly constitutes an important instrument for the dissemination of codified norms, it remains to be established what role hand-written texts played in standardisation processes. In nineteenth-century Europe, mass-literacy, which is generally seen as a precondition of standardisation processes, was only possible because large parts (or even the majority) of the population learnt to write (and read) hand-written texts. In the vast volume of private texts that were produced during the various wars and emigration waves of the nineteenth century, not only codified norms, but also (regional) norms of usage were widely transmitted. Private letters and diaries, in particular, have proved to be a valuable text source for the investigation of such norms and their diffusion (cf. Elspaß, in: Hernández-Campoy, Conde-Silvestre (eds) The handbook of historical sociolinguistics. Wiley-Blackwell, Chichester, 2012). With examples from a corpus of German emigrant letters, the present contribution will try to demonstrate that grammatical norms of usage which were literally not visible in printed texts at the time, but which are now considered standard, formed part of the standardisation process of German.
\end{abstract}

Keywords Language history from below $\cdot$ Private letters $\cdot$ Standardisation · Alternative language histories

I would like to thank Simon Pickl and two anonymous reviewers for helpful comments.

Stephan Elspaß

stephan.elspass@sbg.ac.at

1 University of Salzburg (Austria), Fachbereich Germanistik, Erzabt-Klotz-Straße 1, 5020 Salzburg, Austria 


\section{Introduction and overview}

While four of the contributions to this special issue of Language Policy on Revisiting Haugen. Alternative histories of standardization focus on a particular aspect of Haugen's 1983 model of the "Implementation of Corpus Planning" (Voeste; Hickey; Ayres-Bennett; Rutten et al.) and one contribution addresses ideological aspects of standardisation (del Valle), the present paper seeks to assess the role of data that have not been considered in previous models of standardisation. It will attempt to raise awareness and argue for the use of alternative data. Starting from a discussion of Haugen's model(s) (“'Implementation' and 'acceptance': factors causing confusion about Haugen's model" section) and a reflection on predominant concepts in traditional standardisation histories, including the standard language ideology ("Common concepts of standardisation histories" section), it will put forward arguments for a consideration of alternative data in such histories ("The need for alternative data in histories of standardisation" section) and identify sources of such data ("Alternative sources of data for histories of standardisation from the perspective of a "language history from below", section). The "(Non-)effectiveness of norms, prescriptivism and codifiers in texts "from below" section presents examples from German which demonstrate the need to take into account alternative data in the history of standardisation. The paper will conclude by indicating some key factors which could (or should) "be incorporated into an updated version of a general theory of standardization" (cf. Rutten and Vosters 2017).

\section{"Implementation" and "acceptance": factors causing confusion about Haugen's model}

There has been some confusion as to whether Haugen's model may be interpreted as a descriptive model of standardisation histories or as a framework for language planning. Haugen himself has possibly contributed to this confusion, as he had applied it to both contexts and as he had-in his own words- "fiddled a little with the terms" (Haugen 1983: 269) since the first publication of the matrix model (Haugen 1966a: 933).

The confusion relates to the role of the aspects "implementation" and "acceptance" of language norms in Haugen's model and became noticeable in the seminal volume Germanic Standardization (Deumert and Vandenbussche 2003a). The idea of the volume was to provide-for the first time-a comparative overview of standardisation histories of a large family of the European languages, i.e. the Germanic languages. Some of the contributors referred to Haugen's “four aspects of language development [...] in taking the step from 'dialect' to 'language', from vernacular to standard", that is "(1) selection of norm (2) codification of form (3) elaboration of function, and (4) acceptance by the community" (Haugen 1966a, b: 933), thus arriving at the famous matrix model (ibid.): 


\begin{tabular}{lll}
\hline & Form & Function \\
\hline Society & Selection & Acceptance \\
Language & Codification & Elaboration \\
\hline
\end{tabular}

Some other contributors to the volume, however, took up a modified model in which Haugen had replaced "acceptance" by "implementation", for instance in his 1983 paper on "the implementation of corpus planning" (Haugen 1983), thus arriving at the following version of the matrix (ibid.: 275):

\begin{tabular}{lll}
\hline & Form (policy planning) & Function (language cultivation) \\
\hline Society (status planning) & $(1)$ selection & (3) implementation \\
& $($ decision procedures) $[\ldots]$ & (educational spread) $[\ldots]$ \\
Language (corpus planning) & $(2)$ codification & (4) elaboration \\
& $($ standardization procedures) & (functional development) \\
& {$[\ldots]$} & {$[\ldots]$} \\
\hline
\end{tabular}

In a later article, Haugen again takes up the first version by defining standard language as "a uniform and consistent norm of writing that is widely accepted by its speakers" (Haugen 1994: 4340; my emphasis, S.E.). In the following, I will refer to the first version as the "historical standardisation model" and to the second version as the "standardisation planning model".

In his review of Deumert and Vandenbussche (2003a), Auer (2006: 330) remarked that Haugen's model may be more appropriate as a model for language planning. Auer explicitly refers to the standardisation planning model, in whichas has become clear above-selection and implementation are connected to "status planning", and codification and elaboration to "corpus planning" (Haugen 1983: 275). Based on this notion, Auer questioned whether Haugen's model is at all appropriate for an understanding of the historical processes of standardisation. He writes (my translation):

"Haugen's model also disregards the fact that the standardisation processes in Europe were embedded into the nation state discourses so utterly that it is almost blind to the cultural-historical context." (Auer 2006: 339; my translation, S.E.) ${ }^{1}$

Given the clear connection that Haugen draws between standardization and nationbuilding (e.g. Haugen 1966a, b: 928, 930), this criticism may seem a little overdrawn. However, in an attempt to arrive at a blueprint for standardisation, the more 'mechanical' aspects of Haugen's model have certainly attracted more attention than the individual socio-cultural circumstances under which various standardisation

\footnotetext{
1 "Haugens Modell missachtet auch die Einbettung der Standardentwicklung in Europa in den nationalstaatlichen Diskurs so gründlich, dass es geradezu kulturhistorisch blind ist".
} 
histories have taken place. I will give just one brief example. The standardisation histories of English, French and German differ not only from a chronological point of view, but also with respect to the structure and the sociological forces in this process. The standardisation process in the German-speaking countries started much later than the ones in England and in France, and because it lagged behind compared to the other two 'big' Western European languages, it picked up speed in the nineteenth century, accompanied by massive codification efforts, particularly at the end of the century.

I am not certain what Haugen originally could have had in mind, whether he had actually aspired to adapt a model which primarily tried to capture four aspects of historical standardisation, as in his 1966 paper, as a model for language planning —or vice versa. But historical standardisation and standardisation by language planning may actually be two entirely different things. From this perspective, it is important to note that Haugen's (1983) paper appeared in a volume on language planning. To me, the crucial point for standardisation in history appears to be not implementation, but actual acceptance measured by actual language use, because efforts to implement a norm cannot ensure that this norm will be accepted by the members of the language community. ${ }^{2}$ The norms-and-usage divide can be illustrated with numerous examples from the histories of Dutch, English, French and German compiled in the volume by Rutten et al. (2014), which focuses on the standardisation period of these languages, i.e. 1600-1900.

Another aspect of Haugen's model which has caused some confusion is whether it presents four subsequent stages of a standardisation process or not. In his 1983 paper on "implementation of corpus planning", Haugen writes that while "the four steps [...] show a certain logical succession, they are not necessarily temporarily successive, but may be simultaneous and cyclical" (Haugen 1983: 270). However, the 'steps' metaphor implies that 'steps' follow one after the other. Moreover, the image of 'steps on stairs' has the implication of the conceptual metaphor MORE IS UP or GOOD IS UP (Lakoff and Johnson 1980: 196). Similarly, scholars have repeatedly referred to the 'historical standardisation model' as a model capturing four subsequent stages of a development. Most of the authors of the Deumert and Vandenbussche (2003a) volume actually present the individual steps in a quasichronological order. Other contributors, however, felt compelled to point out that the four phases may overlap. In fact, in Haugen's 1966 paper there is no mention of subsequent stages. He mostly talks of "four aspects of language development" (Haugen 1966a, b: 933).

Having demonstrated a certain confusion in the adaption of Haugen's model and in view of a certain neglect of the cultural-historical contexts of standardisation processes in this model, it may be asked as to what extent the model can be adapted, or if there may even be alternative approaches to describing standardisation processes.

\footnotetext{
2 Successful implementation may ideally include acceptance. In his standardisation planning model, however, Haugen (1983: 272) explicitly refers to "the activity of a writer, an institution, a government in adopting and attempting to spread the language form that has been selected and codified".
} 
To this end, the next section will zoom out from Haugen's model and try to gain a wider picture of common concepts of historical standardisation histories.

\section{Common concepts of standardisation histories}

In order to show what aspects a revised theory of standardisation should encompass, I will briefly try to point out some characteristics of traditional histories of language standardisation and what they have overlooked.

A major feature of traditional histories of standardisation is teleology in the sense of an overall purpose of language change (Milroy 1992: 29; cf. also Roberge 2012: 375 ). It implies that all language developments up to the modern standard have basically served to create this standard. Even Haugen's historical standardisation model has been characterised as being "rather teleological" (cf. Deumert and Vandenbussche 2003b: 10). Using the example of English, Milroy (1992: 51-52) and Watts (2011: 290-294, 2012: 585-587) have both used the 'funnel model' to describe the way in which the standardisation history has been portrayed. Watts writes:

'In the 'funnel view', the wide top of the funnel represents a period in the past in which there was no standard and in which we can find a number of linguistic varieties that seem to be related enough to be grouped together as a 'language'. [...] as we move through time, the wide top of the funnel narrows to a neck through which language varieties muss pass. The bottle would then be the container for the standard, again giving a narrow focus and implying a predestined teleology.' (Watts 2012: 585-586)

According to Watts, the funnel view constitutes a modern 'archive' (in the Foucauldian sense), and "[o]ne way to crack open the archive is to focus more consciously on a range of alternative histories and to investigate the language ideologies that constitute the canonical version" (Watts 2011: 291). The 'funnel model' can easily be adopted to other standardised Western languages. ${ }^{3}$ As for the history of German, Reichmann (2001) has nicely captured the cultural, sociological and ideological motivations for such a purposefully simplifying narrative:

'I would argue that the language historiography of German until well into the second half of the twentieth century was not interested in an objective description of language reality. Rather, it aimed at convincing its readership of the existence of a specific, unique communication system called 'German', a system which is characterised by high structural, semantic and sociological (e.g. literary) standards and which is suitable as a means of constructing or rein-

\footnotetext{
3 Joseph (1987: 20) stresses that "standard language" is not only a modern concept, but also one which is "dependent for [its] definition upon other cultural institutions which represent specific historical developments within Western civilization". Thus, standardisation processes in other hemispheres are beyond the scope of the present paper.
} 
forcing identification and of solidarisation in a linguistic-national and culturalnational sense.' (Reichmann 2001: 533; my translation, S.E. $)^{4}$

In this quote, Reichmann highlights the cultural historical contexts which Auer and others miss in Haugen's standardisation model. The neglect of socio-cultural background information is also noticeable in many diachronic systematisations and language periodisation models to this day. To give just one prominent example, again from the history of German: The periodisation of German-and subsequent accounts of its structural developments - still rests on highly selective and heterogeneous corpora and text genres. While "terms like 'Old High German', 'Middle High German' and 'Early New High German'” etc. "allow for a quick temporal orientation, at the same time, they refer to the general [and utterly diverse] socio-historical context of tradition" (cf. Fleischer and Schallert 2011: 26; my translation and addendum, S.E.). ${ }^{5}$ Thus, rather than describing a continuous language development based on texts from similar communicative contexts, what traditional language histories in actual fact present is a history of German which 'meanders' with respect to sociohistorical contexts and genres that have been handed down to us (cf. Pickl 2016). This is what has been referred to as the "tunnel vision version" (Watts and Trudgill 2002:1) or the "tunnel view" (Watts 2012: 585) of language historiography. And I would argue with Pickl (Pickl 2016) ${ }^{6}$ that the traditional periodisation of the history of German may tell more about the transmission of different text genres than about the changes in the language itself.

Focussing on the standardisation narratives for German and other Germanic languages for the modern period, I have claimed that traditional accounts mainly present "language histories "from above" (Elspaß 2007: 3-5). They are not only characterised by a highly teleological perspective, but also by a bias towards a (supposedly) largely uniform standard language and its development. Such narratives for the modern period are mainly based on printed language, representing 'corrected' texts from highly formal registers and fictional literature, and texts written by a small minority of (privileged) people, mostly men. Moreover, these printed texts never represent the language of the original scribe alone, but of copy editors, printers and so on, who adapted the scripts to some regional or supra-regional norms. In short, such traditional historiographies for the modern period are highly teleological, they are selective and biased towards formal (or fictional) and printed-hence

\footnotetext{
4 "Ich behaupte [...], daß die Sprachgeschichtsschreibung des Deutschen [...] bis weit in die 2. Hälfte des 20. Jahrhunderts, mehr als durch das abbildtheoretisch motivierte Beschreiben objektsprachlicher Verhältnisse durch das Anliegen bestimmt ist, die angesprochene Leserschaft von der Existenz eines spezifischen, eigentümlichen, einmaligen Verständigungssystems 'Deutsch'zu überzeugen, eines Systems, das mit hohen strukturellen, semantischen, soziologischen (z. B. literatursprachlichen) Gütequalitäten ausgezeichnet ist und das sich deshalb gut in den Dienst von Identitätsfindung oder -verstärkung, von Solidarisierung in einem sprach- und kulturnationalen Sinne stellen läßt.”.

5 "[D]ie Termini , althochdeutsch'(ahd.), , mittelhochdeutsch"(mhd.) und ,frühneuhochdeutsch'(fnhd.) [...] erlauben einerseits eine schnelle zeitliche Orientierung, verweisen andererseits aber auch auf den generellen soziohistorischen Kontext der Überlieferung."

${ }^{6}$ Cf. also Pickl (2017: 4) on the consequences of such data selection for the account of the history of negation in German.
} 
'purified' - texts from a privileged minority of the male population, so that they fail to tell the whole standardisation stories. One result of this heavily biased data selection is that such stories arrive at quite early dates for the endpoints (or teloi) of standardisation processes. In the German case, it is maintained that a standard had been arrived at by the end of the eighteenth century (ibid.: 3), in the case of Dutch earlier in the eighteenth century (cf. Rutten and Van der Wal 2014: 3), and in the case of English at the end of the seventeenth century (Watts 2012: 598).

\section{The need for alternative data in histories of standardisation}

What traditional standardisation histories 'from above' mostly do not account for (or what they even ignore) is that a wide range of text genres have existed and continued to widen from early modern time onwards, particularly handwritten material and texts representing orality and oral registers. Moreover, by focusing on writing elites, mostly from the upper classes of society, histories of standardisation 'from above' neglected or even ignored the voices of 'common people'. As handwritten texts from different genres and from writers from all ranks of the society display a wide range of variation, traditional histories of standardisation have also disregarded the histories of (allegedly) 'non-standard' varieties and variants which have notoriously been stigmatised as 'deviant', 'not correct', 'bad' or 'corrupted' language (cf. Davies and Langer 2006 for German) and which thus are "not part of the conceptualization of the history of the language" (Watts 2012: 586). In fact, the notion of homogenous standard varieties and the standard language ideology have often resulted in cleansing out factual variation from corpus data in an act of "sanitary purism" (Milroy 2005: 324-326) or, in other words, data manipulation. Thus, the 'selection' of data which traditional histories of standardisation are based on does not only refer to varieties and registers, but also to a selection of variants to arrive at "a hypothetical, 'pure' variety of a language having only one spelling and one pronunciation for every word, one word for every meaning, and one grammatical framework for all utterances", although "[i]n practice such fixation has proved to be chimerical" (Haugen 1966a: 931). In short, what traditional histories of standardisation 'from above' of most Western language present is an incomplete picture of the standardisation processes.

Apart from the desire to gain as complete a picture as possible of language in the past, one important reason to look for alternative data sources for histories of standardisation is to account for present-day variation. This variation appears not only as a co-existence of different forms for the same function in different non-standard varieties of a language but also within the standard varieties of these languages. As indicated at the end of the previous section, the standard language ideology is inextricably linked to homogenism, i.e. the belief that a standard language is uniform and without variation. In reality, however, there is a wide spectrum of variation within standard varieties. This 'standard variation', as it will be referred to in the following, does not only exist between the different forms of the same language in different states (e.g. British English vs. Irish English vs. Australian English etc.), but also within a state, and it affects all levels of linguistic description. In the case 
of present-day German, diatopic standard variation is captured in three recent codices on lexis (cf. Ammon et al. 2016), grammar (cf. Variantengrammatik des Standarddeutschen 2018) and pronunciation (cf. Kleiner and Knöbl 2015). Consider the following examples: In standard German in Germany, there are three regional lexical variants for 'butcher', i.e. Metzger, Fleischer and Schlachter. Standard German grammar has two plural variants of the word Tunnel 'tunnel', i.e. Tunnel and Tunnels, two auxiliary variants for the perfect tense of the verb stehen 'to stand', ich bin gestanden and ich habe gestanden, and the use of the preposition wegen 'because of' with genitive and with dative is both seen as correct. ${ }^{7}$ In spoken standard German, three regional variants of the pronunciation of the onset consonant in the word Chemie 'chemistry' are considered standard, i.e. [k], [f] and [ç] (cf. Kleiner and Knöbl 2015: 272). The extent of variation is even greater when we take into account other German-speaking countries and regions, such as the eastern part of Belgium, Luxembourg, German-speaking Switzerland, Liechtenstein, Austria and South Tyrol (in the northern part of Italy). Earlier codices would tend to recognise one form only in each case, not because of a lack of standard variation, but because of a restrictive and idealised notion of a 'pure' standard which does not allow for variation.

With respect to an increasing orientation of standard German towards variants that were previously attributed to the (non-standard) spoken language, recent developments have often been characterised as 'destandardisation' (cf. Mattheier 2003: 240). However, as destandardisation is defined as "a possible development whereby the established standard language loses its position as the one and only 'best language"" (Tore Kristiansen, quoted in Auer and Spiekermann 2011: 161), destandardisation would imply the existence of an ideal homogenous standard language as the result of a standardisation process, which in turn would have been geared to this very purpose. In this view, present-day variation in standard languages may be lamented as the consequence of "a general decrease of the degree of standardization (i.e. understood as linguistic uniformity and normativity)" (Mattheier 2003: 240), allowing non-standard varieties and variants to enter formerly (supposedly) 'pure' and homogenous standards.

An alternative explanation of the origin of present-day standard variation is 'demotisation' of the standard in the sense that "the idea of what this 'best language' is, or sounds like, changes" (Tore Kristiansen, quoted in Auer and Spiekermann 2011: 161). From this angle of vision, present-day standard variation rather represents a continuation of variation which has always existed in written language, albeit in more informal registers or in different regions. In fact, the demotisation model would reflect a revalorisation of regional variants and variants from registers which have previously been disregarded as non-standard. Thus, a wider notion of 'standard' may include different registers and different regional centres of standard language usage. This, of course, increases the likelihood and amount of variation, and the argument here is that what has actually changed is not language usage, but the normative evaluation of usage, that is, the view which variants from which registers

\footnotetext{
${ }^{7}$ For these grammatical variants, cf. also Hennig (2016: 868, 923, 1012-1013).
} 
and which regions ${ }^{8}$ should count as standard. Taking the example of ten morphological and morphosyntactic phenomena, Dovalil (2006) has demonstrated that this is what actually happened in German at the turn of the twenty-first century.

In order to verify these assumptions, it needs to be established (a) that codified norms have changed in terms of the 'standardness' of variants, and (b) that there has been a continuation of use of these variants, albeit in different registers. To investigate the latter, it is essential to look at text sources which are alternative to texts 'from above', i.e. text sources representing registers of written language which never entered the funnel neck in the funnel model of traditional language historiography.

\section{Alternative sources of data for histories of standardisation from the perspective of a 'language history from below'}

What sources of data are we looking for? For two obvious reasons, it is clear that only written text sources can be considered. Firstly, only written sources are available. Secondly, present-day Western standard languages have evolved from some written varieties of these languages. Haugen identified the written form of a language as "a significant and probably crucial requirement for a standard language" (Haugen 1966a: 929; cf. also his definition in Haugen 1994: 4340). Hence, the fact that we 'only' have written sources at our disposal in the study of historical linguistics is no essential problem. With respect to histories of standardisation, these are not "bad data" (Labov 1994: 11) because of their written form - for this is exactly the material that is needed-, but for the randomness of the textual tradition. However, studies on standardisation must be concerned about much more texts than those which have been considered so far, particularly for the time since mass literacy, i.e. the early nineteenth century onwards. I will make a case for more hand-written material, and in particular hand-written texts 'from below'.

\section{Hand-written material}

Let us first consider the role of hand-written material. Haugen stated that it "may be questioned whether there were any standardized languages prior to the invention of printing in the fifteenth century" (Haugen 1994: 4340). The role of printing, however, may be overrated. Gutenberg's invention of printing with movable type certainly boosted standardisation processes, but it was not a precondition. As for the German case, von Polenz (2000: 126) contended that "the expansion of the written word in German had [...] already begun a long time before the invention of printing made it possible for the innovation of publication technology to take effect, and this process continued into the twentieth century". 9 Moreover, at least until around

\footnotetext{
8 Provided the standard is not perceived as an entirely supraregional entity.

9 „Die Expansion deutscher Schriftlichkeit war [...] längst in Gang gekommen, ehe mit der Erfindung des Buchdrucks die bis ins 20. Jahrhundert fortwirkende Innovation der Publikationstechnik wirksam werden konnte." (I have translated "Schriftlichkeit" with "the written word" here, as von Polenz focuses on the culture of reading and writing and its role for the standardisation of German, not merely on 'literacy'.).
} 
1800 , and in many regions certainly well into the nineteenth century, the spread of literacy did not necessarily involve printed texts (Messerli 2000), and certainly not formal instruction in schools (e.g. Hinrichs 1982: 97; Tveit 1991). In nineteenthcentury Europe, mass-literacy, which is generally seen as a precondition of standardisation processes, was only possible because large parts (or even the majority) of the population learnt to write (and read) hand-written texts (cf. e.g. Knoop 1994: 866). Despite these known facts, the "ideology of Standardisation" has been built on an exclusive consideration of printed texts (Fairman 2015: 55).

\section{Texts 'from below'}

What it meant by texts 'from below'? In the quest for alternative language histories and for alternative histories of standardisation, I have argued for a focus on the 'roots' of present-day western writing cultures (cf. Elspaß 2005, 2007). A view 'from below' firstly involves an acknowledgment of the language use of larger sections of the population, particularly the lower ranks of the society-including their role as agents in standardisation processes. Secondly, and more importantly, the concept of 'from below' calls for a re-centring of the angle of vision ${ }^{10}$ and for an entirely different starting point for the description and explanation of language history. This would entail not to take texts from formal registers (and certainly not texts written to be printed), but oral and informal language registers in the written medium as the basis of the description of language histories - and also of histories of standardisation. Oral and informal registers are primary and basic to human communication, conceptually written and formal registers are secondary in first language acquisition-most people first encounter them when they begin to attend school and they are the exceptional case. ${ }^{11}$

In the following, I will focus on the second aspect. What are texts 'from below' in the sense of 'oral registers'? They are texts which are close to speech by being either speech-like, speech-based or speech-purposed. ${ }^{12}$ The richest body of texts, written by members from almost all layers of society, comes from private letters, private diaries and other ego-documents (Elspaß 2012). Private letters, in particular, are often perceived by writers as "speech-like" (cf. Elspaß 2005: 61). However, they never represent transcripts of the spoken varieties of their writers. As for the writers of emigrant letters from the nineteenth century, for instance, which the analyses in the "(Non-)effectiveness of norms, prescriptivism and codifiers in texts "from

\footnotetext{
${ }^{10}$ I have happily borrowed a phrase by historian Martyn Lyons which he uses to characterise the "New History from Below" approach (cf. Hitchcock 2004) in historical science: "if we pursue what at first appears marginal with enough determination, we may establish a new core which re-centres the historian's angle of vision." (Lyons 2012: 20).

11 For the corresponding concept of 'orality/language of immediacy versus literacy/language of distance' and its implications for linguistic theory cf. Koch and Oesterreicher (1985 [2012]) and Oesterreicher (1997).

$12 \mathrm{Cf}$. the division of close-to-speech text genres into those which are "speech-like (e.g. private correspondence), speech-based (e.g. trial proceedings) and speech purposed (e.g. plays)" (Nevalainen and Raumolin-Brunberg 2012: 29, after Culpeper/Kytö (2010)).
} 
below" section are based on, it has to be stressed that the written varieties which they used in their letters, although informal, were entirely different from the spoken dialects that they had grown up with and that they used in their everyday communication. ${ }^{13}$ Moreover, historical texts 'from below' in the sense of 'oral' and 'informal' did not necessarily originate from the lower ranks of the society. To give just two prominent examples from German:

- After Ludwig van Beethoven had gradually lost his hearing abilities, he and his family and friends used so-called 'conversation notebooks'. Beethoven's conversation notebooks have been transcribed and edited in an eleven-volume critical edition. They certainly represent a "speech-like" (or rather "speech-compensating') text source from the beginning of the nineteenth century (cf. Sato 2015).

- Sermons are either "speech-based" or "speech-purposed", but some sermons are "written to be printed", but it can be argued that even then they are "speechlike". Sermons in German are, by the way, one of the few text genres-if not the only one-which have been written down and transmitted throughout the entire history of written German (cf. Pickl 2017).

All these texts represent 'historically oral registers' in one way or other. A particular advantage of such texts is that they provide specific lexical and grammatical material, which can be completely lacking in a corpus of printed texts, such as forms of address and second person forms from verbal paradigms.

\section{(Non-)effectiveness of norms, prescriptivism and codifiers in texts 'from below'}

In what way can such texts 'from below' be important for our understanding of language history, and in what respect can a consideration of variation in such texts broaden our knowledge on standardisation processes? In the vast volume of private correspondence that was produced particularly during the various wars and emigration waves of the nineteenth century, not only codified norms but also norms of usage were widely transmitted, if sometimes only with regional reach. Such norms of usage include variants that can play an important but hitherto neglected role in standardisation processes. I will present three examples which are from a corpus of German emigrant letters from the nineteenth century (cf. Elspaß 2005: 55-72 for details on this corpus). I selected three grammatical variants which are known to be used in non-standard varieties of German, but which have recently also emerged in standard varieties of German: the use of dative after the preposition wegen, the 'split form' and the 'doubling construction' of pronominal adverbs, and final schwa

\footnotetext{
13 From the viewpoint of language acquisition, to such writers the language which they use in these documents clearly has all the properties which are attributed to standard language, i.e. it was acquired "through INSTRUCTION, CORRECTION, IMITATION, ASSIMILATION, ACCULTURATION-precisely the ways in which one's native dialect is not acquired" (Joseph 1987: 19).
} 
deletion in the first person singular of verbs. All three variants are also known to have been declared 'incorrect' in nineteenth century grammars. The question arises, if and-if yes - to what extent these variants were used in printed texts and in texts 'from below'. If they prove to be absent both in texts 'from above' and 'from below', this will be interpreted as a successful prescription of a codified norm. If they prove to be absent in print, but in regular use in texts 'from below', this will be taken as a case of limited effectiveness of prescriptive norms and the existence of norms of usage 'beyond' the codified norms of the time. In principle, this procedure follows the norms-and-usage approach in recent historical sociolinguistic research (cf. the contributions in Rutten et al. 2014), however, with a distinct focus on norms of usage in historical texts 'from below' and their impact on present-day standard variation.

\section{Historical and present-day variation of the prepositional case after wegen}

Some of the frequently used prepositions in German, such as wegen 'because of', show variation between the genitive and the dative case in the following noun phrase. In "everyday speech", wegen with the dative is "frequently used" (Durrell 2017: $490^{14}$ ). In standard German, the genitive is dominant, but the dative is useddepending on regional use-between 1 and $31 \%$ (cf. Variantengrammatik des Standarddeutschen $2018^{15}$ ). For traditionalists, this may be interpreted as a symptom of 'destandardisation', provided that the genitive is seen as the only standard norm at the peak and end point of the standardisation process. An analysis of printed prose texts by Sato (2015) reveals that the grammaticalisation of wegen from a noun to a postposition with a genitive, then to a preposition with a genitive and further to a preposition with a dative was almost complete at the end of the eighteenth century. But then this process was reversed, after the leading grammarian of the time, Johann Christoph Adelung, had prescribed the genitive in his highly influential school grammar (Adelung 1781: 349). Subsequently, the use of the dative declined rapidly, but only in printed texts. In written private texts in the nineteenth century, the dative case, cf. example (1), remained predominant (Elspaß 2015: 47-48). In 93.8\% of relevant instances $(N=65)$ in letters by lesser educated writers, wegen is used with the dative (or even an accusative form).

\footnotetext{
ich bin wegen dem Geld nicht Soldat geworden (from Elspaß 2005: 321)

I am because of the-DAT money not soldier become

'I did not become a soldier because of the money.'
}

\footnotetext{
${ }^{14}$ Cf. also an illustrative map from the Atlas of Colloquial German (Elspaß and Möller 2003ff.), http:// www.atlas-alltagssprache.de/wp-content/uploads/2012/05/wegen_des-dem.jpg Accessed 28 December 2018.

15 The highest proportions of the use of wegen with the dative are in Liechtenstein (31\%) Switzerland (16\%) and the western part of Austria, cf. http://mediawiki.ids-mannheim.de/VarGra/index.php/Wegen. Accessed 28 December 2018.
} 
Thus, the predominance of the dative after wegen in everyday spoken German may not be the only reason for its occurrence as a variant in standard written and spoken German. Apparently, the continuous use of the dative in spoken and written German never stopped, although in writing it was, from the beginning of the nineteenth century until recently, limited to texts from informal registers.

The 'prescriptive history' of this preposition is an illustrative example of the change in normative valuation (cf. Davies and Langer 2006: 265-266): Whereas the seventeenth century saw conflicting normative statements about the status of wegen + dative, the dative case after wegen was clearly rejected as 'incorrect' from the end of the eighteenth to well into the twentieth century. Recent decades, however, have seen a revalorisation that takes into account register variation, functional variation and regional variation so that nowadays wegen + dative is considered acceptable as standard variant in certain contexts and regions (cf. Dovalil 2006: 98-100; Hennig 2016: 1012-1013; Variantengrammatik des Standarddeutschen 2018).

\title{
Historical and present-day variation of pronominal adverbs
}

The second example relates to pronominal adverbs and their variants in German. Pronominal adverbs in German (and Dutch) are formed from the R-pronouns $d a-$, wo- and hier- (named after the historical forms which all contained a final $-r$, cf. Old High German dâr, wâr, hiar) and primary prepositions, such as mit 'with', von 'of', bei 'at' etc. (cf. Fleischer 2002a, b: 117-118). Most present-day grammars maintain that pronominal adverbs can only be used as a single-word form in standard German, e.g. damit 'therewith, with that', hiermit 'herewith', wovon 'whereof' etc., cf. example (2).

\author{
damit habe ich nichts zu tun \\ this-PRO-with have I nothing to do \\ da habe ich nichts mit zu tun \\ this-PRO have I nothing with to do \\ da habe ich nichts damit zu tun \\ this-PRO have I nothing this-PRO-with to do \\ 'I have nothing to do with this'
}

In colloquial German as well as in spoken standard German, however, several variants with discontinuous forms are in use, and they have recently started to emerge in written standard German (cf. Negele 2012: 241-244; Variantengrammatik des Standarddeutschen 2018). ${ }^{16}$ Only two variants may be highlighted here, the 'split form', cf. example (3), and the 'doubling construction', in which the PRO adverbial is resumed, cf. example (4). I will not go into a discussion of the syntactic status and implications of these two variants. Suffice it to say that they are

\footnotetext{
${ }^{16} \mathrm{Cf}$. http://mediawiki.ids-mannheim.de/VarGra/index.php/Spaltung_von_Pronominaladverbien Accessed 28 December 2018.
} 
cross-linguistically not uncommon, e.g. other West Germanic languages like Dutch have it (cf. Fleischer 2002a, b: 131-147; Negele 2012: 184-199). What is remarkable in present-day German is the clear regional distribution: The 'split form' is used predominantly in the north, and the 'doubling construction' mostly in the south. This is attested for colloquial German ${ }^{17}$ as well as standard German contexts. ${ }^{18}$ As for the history of these forms, again, the stigmatisation started in the late eighteenth century (cf. Negele 2012: 229-231). However, when grammarians bother to mention a supposedly 'wrong' form, it can almost be taken as evidence that they were in use in written texts. In contrast to printed texts from the nineteenth century, discontinuous forms are used commonly in the nineteenth century letter corpus. And here, they already show a north-south distribution as they do today (ibid: 121-122). Thus, pronominal adverbs and their discontinuous variants present another case in which present-day standard variation can be traced back to variation in historical text 'from below'.

\section{Historical and present-day variation of 1st pers. sg. pres. ind. form of verbs}

The third example focuses on a phenomenon, reported by Auer and Spiekermann (2011), which at first glance seems to only affect phonological variation in presentday spoken standard German. While salient regional features, such as the coronalisation of the voiceless palatal fricative /ç/ (in the West and East Central German area) or the lenition of intervocalic fortis consonants (e.g. in West Upper German area), show a clear decline in the spoken standard (ibid.: 168, 170), other forms are "advancing rapidly" and "spread[ing] over the whole country" (by which Auer and Spiekermann 2011: 173 mean Germany). One prominent example is the deletion of final schwa in the first person singular present indicative of frequent verbs. These allegro forms "clearly diverge from the written standard and also from the old [spoken] norm established in the late nineteenth century" (ibid.). Again, written representations of such 'non-standard' forms of deletion are quite common in the letter corpus. As for the first person singular forms of kommen 'to come', haben 'to have', gehen 'to go', the variant ich komm instead of the 'correct' spelling ich komme 'I come' is used in $6.8 \%$ of all instances $(N=44)$, ich hab instead of ich habe 'I have' in $9.1 \%$ of all instances $(N=1264)$, and ich geh instead of ich gehe 'I go' in almost every eighth instance $(12.3 \%, N=57)$ (Elspaß 2005: 445). Even in presentday standard German, such variants with deletion of schwa-e are not restricted to the spoken medium. They are also used in the representation of direct speech in written standard German texts from the south of Germany and from Austria. ${ }^{19}$ These are actually regions in which the apocope of the first person singular forms was a frequently used spelling variant until the late eighteenth century (cf. Rössler 2005: 319). As far as the socio-historical context is concerned, this is exactly the period of

\footnotetext{
17 Cf. http://www.atlas-alltagssprache.de/runde-2/f21a-c/ Accessed 28 December 2018.

$18 \mathrm{Cf}$. link in footnote 18 .

19 Cf. http://mediawiki.ids-mannheim.de/VarGra/index.php/E-Ausfall_bei_häufigen_Verben Accessed 28 December 2018.
} 
time when, virtually by order of Empress Maria Theresia and Emperor Joseph II., the Austrian authorities adopted the Deutsche Sprachkunst by the German grammarian Johann Christoph Gottsched (1748), who-among other characteristics of the Upper German varieties-rejected the use of the apocope in his codex.

\section{Discussion}

In all three cases, non-dominant and formerly stigmatised variants of present-day spoken and written standard German-the use of dative after the preposition wegen, the 'split form' and the 'doubling construction' of pronominal adverbs, and final schwa deletion in the first person singular of verbs-could be traced back to the beginnings of the standardisation period. Whereas in nineteenth-century printed German these variants did not come to light, it could be demonstrated that they were regularly (in the case of wegen with the dative case even predominantly) used in nineteenth century private correspondence, i.e., in the terminology suggested in this paper, in texts 'from below'. Clearly, their absence from printed text sources did not mean that they were not part of written German usage at that time (and earlier). Thus, it becomes evident that a view of standardisation that is limited to printed text alone would overlook factual variation in written language from the past. While many phonological, lexical and grammatical variants never became standard, others which seem to have only recently emerged in standard varieties of German had actually been employed for a long time.

A common explanation for their supposedly sudden emergence in present-day German has been 'destandardisation', which implies that the supposedly homogenous standard language has lost its position as the one and only 'best language', allowing variants from non-standard spoken varieties (dialects, regiolects, sociolects) to enter the standard (or even permitting formerly non-standard varieties to replace the established standard). The perception of a 'destandardisation' process may have been fostered by the introduction and spread of oral media, such as film, television, radio, and by the dissemination of the spoken and the written word via internet, which have helped to make such varieties and variants more evident to a wider public. A more plausible explanation is that there has been a continuous use of such variants in the written language throughout the modern period. Based on the notion of 'demotisation', the argument that I want to put forward here is that what has actually changed is not the overall usage, but the codified language norms and the idea what is the 'best language' in the sense of what we now call 'standard'. The change of norms is fundamentally related to the question of which registers the standard may include and which variants the standard does encompass. From the time of prescriptivism onwards, the printed language of the time was mostly restricted to the use of codified variants; texts that were intended for printing were corrected by proof-readers and printers to ensure that they conformed to 'printing standards'. Other variants, that were henceforth declared 'deviant' or outright 'incorrect' by prescriptive grammars, continued to be employed in hand-written texts from informal registers only. According to the concept of 'demotisation', such registers have been revalorised so that variants from such registers, which were previously 
considered non-standard, are currently viewed as acceptable in standard German. This revalorisation applies to the variants which were analysed in the present section, but also to some of the variants mentioned in "The need for alternative data in histories of standardisation" section.

From this perspective - and to eventually return to Haugen's historical standardization model-, 'acceptance by the community' appears to be a factor which perhaps deserves more attention in an updated version of the theory of standardisation. The most reliable way to establish the acceptance of a linguistic variant or variety by a community is to look at actual language usage. The history of standardization in German, measured by actual usage, demonstrates that it is the acceptance of what is counted as a standard that can vary - without calling the authority of the standard as such into question.

\section{Conclusion: a research program}

The aim of this paper was to demonstrate that alternative text sources, and private letters, in particular, are not only valuable but also indispensable text sources for the investigation of histories of standardisation. I tried to exemplify this by norms of usage in German, which were not visible ${ }^{20}$ in printed texts of the prescriptive period (late eighteenth to mid-twentieth century), but which are now considered variants of present-day standard. Hence, the modern notion of standard is extended to incorporate variants which had previously been stigmatised from a prescriptive point of view. My main argument was that such variants formed part of the standardisation process of German and that, in order to trace the trajectories of such variants, we have to extend existing corpora to different written registers. As existing corpora mainly represent language 'from above', for the time being, a focus on sources of language 'from below' would constitute the next methodological step. Thus, on the one hand, texts from more informal registers might be seen as nothing more than additional sources of histories of standardisation. On the other hand, however, they open up a completely new perspective on such histories, i.e. a view 'from below'. Therefore, it may seem justified to refer to them as alternative sources for such histories.

In their call for papers, Rutten and Vosters (2017) asked for "results, approaches, insights and methods", which are considered "crucial for a revisited understanding of standardization" in order "to arrive at a list of phenomena that should be incorporated into an updated version of a general theory of standardization". Such a list would certainly call for joint efforts and require an extensive research programme. To me, a revised general theory of standardisation would have to account for

- the ideological background of standardisation, codification and prescriptivism,

- the socio-historical context in which the emergence of certain varieties and variants which were to become 'standard' were embedded,

${ }^{20}$ Cf. Havinga and Langer (2015) for the concept of "invisible languages [and language varieties]". 
- the notion of standard variation and the historical trajectories of variants in the written mode,

- which ultimately requires a consideration of corpora from all written registers, which for the modern period means a consideration of text sources other than printed sources, in particular.

Acknowledgements Open access funding provided by Paris Lodron University of Salzburg.

Open Access This article is distributed under the terms of the Creative Commons Attribution 4.0 International License (http://creativecommons.org/licenses/by/4.0/), which permits unrestricted use, distribution, and reproduction in any medium, provided you give appropriate credit to the original author(s) and the source, provide a link to the Creative Commons license, and indicate if changes were made.

\section{References}

Adelung, J. C. (1781). Deutsche Sprachlehre. Zum Gebrauche der Schulen in den Königl. Preuß. Landen. Berlin: Voß.

Ammon, U., Bickel, H., Lenz, A. N., et al. (2016). Variantenwörterbuch des Deutschen. Die Standardsprache in Österreich, der Schweiz, Deutschland, Liechtenstein, Luxemburg, Ostbelgien und Südtirol sowie Rumänien, Namibia und Mennonitensiedlungen (2nd ed.). Berlin: de Gruyter.

Auer, P. (2006). Review of Deumert \& Vandenbussche. 2003. Zeitschrift für Dialektologie und Linguistik, 72(3), 338-339.

Auer, P., \& Spiekermann, H. (2011). Demotisation of the standard variety or destandardisation? In T. Kristiansen \& N. Coupland (Eds.), Standard languages and language standards in a changing Europe (pp. 161-176). Oslo: Novus.

Davies, W. V., \& Langer, N. (2006). The making of bad language. Lay linguistic stigmatisations in German: Past and Present. Frankfurt am Main: Lang.

Deumert, A., \& Vandenbussche, W. (Eds.). (2003a). Germanic standardizations. Past to present. Amsterdam: Benjamins.

Deumert, A., \& Vandenbussche, W. (2003b). Standard languages. Taxonomies and histories. In A. Deumert \& W. Vandenbussche (Eds.), Germanic standardizations. Past to present (pp. 1-14). Amsterdam: Benjamins.

Dovalil, V. (2006). Sprachnormenwandel im geschriebenen Deutsch an der Schwelle zum 21. Jahrhundert. Die Entwicklung in ausgesuchten Bereichen der Grammatik. Frankfurt am Main [etc.]: Lang.

Durrell, M. (2017). Hammer's German grammar and usage (6th ed.). London: Routledge.

Elspaß, S. (2005). Sprachgeschichte von unten. Untersuchungen zum geschriebenen Alltagsdeutsch im 19. Jahrhundert. Tübingen: Niemeyer.

Elspaß, S. (2007). A twofold view 'from below': new perspectives on language histories and language historiographies. In S. Elspaß, N. Langer, J. Scharloth, \& W. Vandenbussche (Eds.), Germanic language histories 'from below' (1700-2000) (pp. 3-9). Berlin: de Gruyter.

Elspaß, S. (2012). The use of private letters and diaries in sociolinguistic investigation. In J. M. Hernández-Campoy \& J. C. Conde-Silvestre (Eds.), The handbook of historical sociolinguistics (pp. 156169). Chichester: Wiley-Blackwell.

Elspaß, S. (2015). Private letters as a source for an alternative history of Late Modern German. In A. Auer, D. Schreier, \& R. J. Watts (Eds.), Letter writing and language change (pp. 35-52). Cambridge: Cambridge University Press.

Elspaß, S., \& Möller, R. (2003ff.). Atlas zur deutschen Alltagssprache (AdA). www.atlas-alltagssprache. de. Accessed 28 Dec 2018.

Fairman, T. (2015). Language in print and handwriting. In A. Auer, D. Schreier, \& R. J. Watts (Eds.), Letter writing and language change (pp. 53-71). Cambridge: Cambridge University Press. 
Fleischer, J. (2002a). Die Syntax von Pronominaladverbien in den Dialekten des Deutschen: eine Untersuchung zu Preposition Stranding und verwandten Phänomenen. Stuttgart: Steiner.

Fleischer, J. (2002b). Preposition stranding in German dialects. In S. Barbiers, L. Cornips \& S. van der Kleij (Eds.), Syntactic Microvariation. Online proceedings-workshop on syntactic microvariation. 30-31 August 2000 (pp. 116-151). Amsterdam: Meertens Instituut. https://www.meertens.knaw.nl/ books/synmic/pdf/fleischer.pdf Accessed 28 Dec 2018.

Fleischer, J., \& Schallert, O. (2011). Historische Syntax des Deutschen. Eine Einführung. Tübingen: Narr.

Gottsched, J. C. (1748). Grundlegung einer deutschen Sprachkunst. Leipzig: Breitkopf.

Haugen, E. (1966a). Dialect, language, nation. American Anthropologist, 68, 922-935.

Haugen, E. (1966b). Linguistics and language planning. In W. Bright (Ed.), Sociolinguistics (pp. 50-71). The Hague: Mouton.

Haugen, E. (1983). The implementation of corpus planning: Theory and practice. In J. Cobarrubias \& J. A. Fishman (Eds.), Progress in language planning: International perspectives (pp. 269-289). Berlin: de Gruyter.

Haugen, E. (1994). Standardization. In R. E. Asher (Ed.), The encyclopedia of language and linguistics (Vol. VIII, pp. 4340-4342). Oxford: Pergamon.

Havinga, A., \& Langer, N. (Eds.). (2015). Invisible languages in the nineteenth century. Oxford: Lang.

Hennig, M. (Ed.). (2016). Duden. Richtiges und gutes Deutsch. Das Wörterbuch der sprachlichen Zweifelsfälle (8th ed.). Berlin: Dudenverlag.

Hinrichs, E. (1982). Wie viele Menschen konnten in Deutschland um 1800 lesen und schreiben? In H. Ottenjann \& G. Wiegelmann (Eds.), Alte Tagebücher und Anschreibebücher. Quellen zum Alltag ländlicher Bevölkerung in Nordwesteuropa (pp. 85-103). Münster: Coppenrath.

Hitchcock, T. (2004). A new history from below. History Workshop Journal, 57(1), 294-298.

Joseph, J. E. (1987). Eloquence and power. The rise of language standards and standard languages. Oxdord: Blackwell.

Kleiner, S., \& Knöbl, R. (2015). Duden. Das Aussprachewörterbuch (7th ed.). Berlin: Dudenverlag.

Knoop, U. (1994). Entwicklung von Literalität und Alphabetisierung in Deutschland. In H. Günther \& O. Ludwig (Eds.), Schrift und Schriftlichkeit. Ein interdisziplinäres Handbuch internationaler Forschung (Writing and its use. An interdisciplinary handbook of international research) (Vol. 1, pp. 859-872). Berlin: de Gruyter.

Koch, P., \& Oesterreicher, W. (1985). Sprache der Nähe-Sprache der Distanz. Mündlichkeit und Schriftlichkeit im Spannungsfeld von Sprachtheorie und Sprachgeschichte. Romanistisches Jahrbuch 36, 15-43. [English translation: Koch, P., \& Oesterreicher, W. (2012). Language of Immediacy-Language of Distance: Orality and literacy from the perspective of language theory and linguistic history. In C. Lange, B. Weber, \& G. Wolf (Eds.), Communicative Spaces. Variation, Contact, and Change. Papers in Honour of Ursula Schaefer (pp. 441-473). Frankfurt a.M. [etc.]: Lang.].

Labov, W. (1994). Principles of linguistic change. Vol. 1: Internal Factors. Oxford: Blackwell.

Lakoff, G., \& Johnson, M. (1980). The metaphorical structure of the human conceptual system. Cognitive Science, 4, 195-208.

Lyons, M. (2012). The writing culture of ordinary people in Europe, c. 1860-1920. Cambridge: Cambridge University Press.

Mattheier, K. J. (2003). German. In A. Deumert \& W. Vandenbussche (Eds.), Germanic standardizations. Past to present (pp. 212-244). Amsterdam: Benjamins.

Messerli, A. (2000). Das Lesen von Gedrucktem und das Lesen von Handschriften-zwei verschiedene Kulturtechniken? In A. Messerli \& R. Chartier (Eds.), Lesen und Schreiben in Europa 1500-1900 Vergleichende Perspektiven (pp. 235-246). Basel: Schwabe.

Milroy, J. (1992). Linguistic variation and change. On the historical sociolinguistics of English. Oxford: Blackwell.

Milroy, J. (2001). Language ideologies and the consequences of standardization. Journal of Sociolinguistics, 5(4), 530-555.

Milroy, J. (2005). Some effects of purist ideologies on historical des-criptions of English. In N. Langer \& W. V. Davies (Eds.), Linguistic purism in the Germanic languages (pp. 324-342). Berlin: de Gruyter.

Negele, M. (2012). Varianten der Pronominaladverbien im Neuhochdeutschen. Grammatische und soziolinguistische Untersuchungen. Berlin: de Gruyter.

Nevalainen, T., \& Raumolin-Brunberg, H. (2012). Historical sociolinguistics: Origins, motivations, and paradigms. In J. M. Hernández-Campoy \& J. C. Conde-Silvestre (Eds.), The handbook of historical sociolinguistics (pp. 22-40). Chichester: Wiley-Blackwell. 
Oesterreicher, W. (1997). Types of orality in text. In E. Bakker \& A. Kahane (Eds.), Written voices, spoken signs (pp. 190-214). Cambridge: Harvard University Press.

Pickl, S. (2016). A diachronic corpus of sermons tracing grammatical change throughout the history of German. Paper presented at the conference Diachronic Corpora, Genre, and Language Change, 8-9 April 2016, University of Nottingham. https://www.nottingham.ac.uk/conference/fac-arts/clas/dcglc /home.aspx Accessed 28 December 2018.

Pickl, S. (2017). Neues zur Entwicklung der Negation im Mittelhochdeutschen. Grammatikalisierung und Variation in oberdeutschen Predigten. Beiträge zur Geschichte der deutschen Sprache und Literatur (PBB), 139(1), 1-46.

Reichmann, O. (2001). Nationale und europäische Sprachgeschichtsschreibung. Mitteilungen des Deutschen Germanistenverbandes, 48(4), 530-537.

Roberge, P. T. (2012). The teleology of change: Functional and non-functional explanations for language variation and change. In J. M. Hernández-Campoy \& J. C. Conde-Silvestre (Eds.), The handbook of historical sociolinguistics (pp. 369-386). Chichester: Wiley-Blackwell.

Rössler, P. (2005). Schreibvariation-Sprachregion-Konfession. Graphematik und Morphologie in österreichischen und bayerischen Drucken vom 16. bis ins 18. Jahrhundert. Frankfurt a. M. etc.: Lang.

Rutten, G., \& van der Wal, M. J. (2014). Letters as loot. A sociolinguistic approach to seventeenth-and eighteenth-century Dutch. Amsterdam: Benjamins.

Rutten, G., \& Vosters, R. (2017). Revisiting Haugen. Alternative histories of standardization. Panel to be submitted to the International conference on language variation in Europe (ICLAVE 9), Universidad de Málaga (Spain), 6-9 June 2017. http://studyres.com/doc/19415683/book-of-abstracts Accessed 28 December 2018.

Rutten, G., Vosters, R., \& Vandenbussche, W. (Eds.). (2014). Norms and usage in language history, 1600-1900. A sociolinguistic and comparative perspective. Benjamins: Amsterdam.

Sato, M. (2015). "Wegen dem Clavier". Die Beethovens und der Rektionswandel der Präpositionen wegen, statt und während im Zeitraum von 1520-1870. Muttersprache. Vierteljahrsschrift für deutsche Sprache, 125, 23-56.

Tveit, K. (1991). The development of popular literacy in the nordic countries. A comparative historical study. Scandinavian Journal of Educational Research, 35(4), 241-252.

Variantengrammatik des Standarddeutschen. (2018). An open access online reference work compiled by a team under the leadership of C. Dürscheid, S. Elspaß, \& A. Ziegler. http://mediawiki.ids-mannh eim.de/VarGra/index.php/. Accessed 28 Dec 2018.

von Polenz, P. (2000). Deutsche Sprachgeschichte vom Spätmittelalter bis zur Gegenwart. Vol. I: Einführung, Grundbegriffe. 14. bis 16. Jahrhundert. 2. rev. and ext. ed. Berlin: de Gruyter.

Watts, R. (2011). Language myths and the history of English. Oxford: Oxford University Press.

Watts, R. (2012). Language myths. In J. M. Hernández-Campoy \& J. C. Conde-Silvestre (Eds.), The handbook of historical sociolinguistics (pp. 585-606). Chichester: Wiley-Blackwell.

Watts, R., \& Trudgill, P. (Eds.). (2002). Alternative histories of english. London: Routledge.

Publisher's Note Springer Nature remains neutral with regard to jurisdictional claims in published maps and institutional affiliations. 